\title{
Letrônica
}

\section{Querida filha, queridos pais: o uso da carta na ficção de Erico Verissimo}

\author{
Dear daughter, dear parents: the use of the letter in the fiction of Erico Verissimo
}

Márcio Miranda Alves ${ }^{1}$

1 Doutor em Teoria Literária e Literatura Comparada pela Universidade de São Programa de Pós-Graduac̃a em Les no Cultura e Regionalidade na Universidade de Caxias do Sul (UCS), onde desenvolve o projeto de pesquisa "Representações identitálas regionais na obra de ficção de Erico Verissimo: interculturalidade e

mirandaalvesm@gmail.com
RESUMO: Embora os romances de Erico Verissimo não sejam epistolares stricto sensu, a carta surge como um elemento importante na estrutura da obra ficcional do escritor. Neste artigo pretendemos mostrar que, como recurso narrativo, essas cartas revelam não apenas o íntimo das personagens, mas, também, introduzem questões históricas e sociais pertinentes à representação literária. Como orientação teórica, trabalhamos com os apontamentos de Watt (2010) e Lajolo (2002).

PALAVRAS-CHAVE: Erico Verissimo; Cartas; Literatura brasileira.

ABSTRACT: Although Erico Verissimo's novels are not epistolary strict sense, the letter appears as an important element in the structure of writer's fictional work. In this article we intend to show that, as a narrative feature, these letters reveal not only the depths of the characters, but also introduce historical and social issues which are relevant to the literary representation. As theoretical orientation we work with the notes of Watt (2010) and Lajolo (2002).

KEYWORDS: Erico Verissimo; Letters; Brazilian Literature. 
e tomarmos a larga produção romanesca do escritor gaúcho Erico Verissimo como um projeto literário consciente, que tenta representar em sua obra dos anos 30 aos 70 diversos fenômenos sociais, culturais, políticos e econômicos do Rio Grande do Sul, do Brasil e do exterior, podemos analisar as técnicas usadas para que a ficção não se tornasse puro relatório historiográfico ou se restringisse a descrições temporais.

Em uma primeira análise, pode-se observar nas obras do escritor uma pluralidade significativa de vozes narrativas que procuram dar conta não apenas da representação histórica, mas, também, da complexidade psicológica das personagens. Dono de um estilo próprio, notadamente inspirado na técnica do contraponto, Erico Verissimo aposta no entrecruzamento de posições de classe, de ideologia e de temperamento de suas criaturas, bem como de recursos narrativos no processo da escrita. Se por um lado esses cruzamentos permitem a exposição de um determinado problema por diversos ângulos, por outro a variedade de recursos técnicos garante a sustentação da estrutura dos romances, condição diretamente ligada à verossimilhança das personagens. Nesse sentido percebemos na ficção do escritor uma simbiose constante entre estrutura e personagem, em que os eventos registrados em documentos primários e secundários são dispostos de forma a sustentar a base do drama central.

Esses documentos, inventados pelo narrador ou representados a partir de registros reais, aparecem nas obras na forma de reportagem de jornais e revistas, áudio de programas de rádio, textos de almanaques, relatórios de pesquisas, relatos orais, diários e cartas. Estes dois últimos têm na ficção de Erico Verissimo a função de revelar pensamentos de foro íntimo das personagens, tornando-as mais próximas do leitor, ao mesmo tempo em que seus apontamentos contribuem de alguma forma para preencher o quadro histórico da narrativa. Por uma questão de foco e prioridade, analisaremos nesse momento a ocorrência da epístola nos romances Clarissa (2005), O tempo e o vento (1956), O senhor embaixador (1997), Olhai os lírios do campo (1997), Incidente em Antares (2000) e Música ao longe (1987), deixando o diário (de Sílvia, Clarissa, Floriano, Francisco Terra, entre outros) para uma ocasião oportuna.

Inicialmente podemos dizer que o escritor faz uso da carta tanto para ampliar as possibilidades do fluxo de consciência de suas personagens, revelando o seu caráter, a sua índole e intenções, quanto para auxiliar o narrador onisciente em seu trabalho de contar a história sem economia de recursos, mesmo que para isso tenha que quebrar o ritmo da narrativa. Essa estratégia sugere um romancista cauteloso que prefere o método indireto ao direto, no sentido de que a narrativa deve falar o quanto possível por si mesma, sem a necessidade constante de explicações ou descrições. Sobre essa opção por um ou outro método nos fala Lubbock que

O simples narrador começa dirigindo-se francamente ao leitor, e depois troca esse sistema por outro, e mais outro, e a cada modificação atinge o leitor de nova distância. 0 processo mais indireto usado pelo autor produz no leitor um efeito mais direto; daí que em igualdade de condições, o meio mais dramático supera o menos dramático. É indireto, como método; mas coloca a própria coisa à vista, em lugar de recordá-la, de refleti-la, de retratá-la. Para cada história existe, sem dúvida, um ponto ideal nessa marcha rumo ao drama, em que o autor encontra o método certo de contar a história. (1976, p. 96)

Na obra de Erico Verissimo a epístola aparece com frequência e funciona como um meio de narrar de maneira indireta, perfeitamente aceitável dentro da forma literária, como vimos na acepção de Lubbock. No momento em que opta por esse recurso, o escritor dialoga com a tradição do romance epistolar, que tem suas raízes na antiguidade como gênero poético e se multiplica no século XVIII com escritores como Richardson, Goethe e Fielding. Evidentemente os romances de Erico Verissimo não são epistolares stricto sensu, mas essa técnica contribui decisivamente para configuração 
da estrutura narrativa. Nesses casos a epístola tem um papel muito mais diegético, ou seja, como elemento que garante coesão à história contada, do que mimético, quando utilizada para imitar a realidade (VALENTIM, 2006, p. 15).

Ao analisar a importância da carta para a ficção de Richardson, Watt (2010, p. 206) observa que ela proporcionou "um atalho para o coração e estimulou-o a expressar com a maior precisão possível o que ali encontrou". Dessa forma os leitores encontravam em suas obras "o registro completo dos próprios sentimentos e o mesmo mergulho num mundo imaginário vibrante de relacionamentos pessoais mais satisfatórios que os da vida real" (WATT, 2010, p. 206).

Algo assim observamos em Clarissa, cuja primeira edição data de 1935. Embora apareçam poucos registros de epístola no romance, eles são suficientes para ampliar a empatia do leitor com a personagem, uma jovem que vive com a tia, em Porto Alegre, onde estuda para ser professora, e se emociona a cada carta recebida, "sempre no mesmo papelzinho de xadrez, com a mesma letrinha redonda, tinta roxa..." (VERISSIMO, 2005, p. 55). Em Clarissa, as cartas trocadas entre mãe e filha servem para atenuar a saudade da protagonista e, em algumas linhas, apontar os problemas sociais da época representada.

\section{Querida filha:}

Estimo que estas poucas e mal trassadas linhas va-te encontrar em goso de perfeita saude, nós vamos indo graças a Deus teu pai é que anda aborrecido por causa dos negossios mas não há de ser nada si Deus quizer e Maria Santissima. Clarissa vou-te mandar um lenço de ceda azul e incarnado disque agora estão usando muinto não vás apanhar algum frio minha filha estás ficando mossa é perigoso e deves ter muinto cuidado com os bondes e autos e que cidade grande é o diabo. Quando o seu Fedencio Fagundes for aí levar a mulher que vai fazer operação de pendicite eu te mando por ele a pecegada para ti comer e dá um pedasso para a tua tia Eufrasina, tão boa comtigo a coitada e tu podes botar sapato de salto alto quando fazeres quatorze anos si Deus quizer e a Virgem, ando muinto aborrecida os negossios anda ruim teu pai não achou comprador para o gado e seu Antunes prometeu comprar mas depois desestiu o semvergonha e tu não vai muinto a sinema que eu não gosto dessas mistura com gente de cidade grande. Dá um abraço na Eufrasina e no Couto e aceite mil beijos da tua mãe e de teu pai. (VERISSIMO, 2005, p. 56 - grifos do original)

A partir do conteúdo dessa carta podemos saber o que se passa em Jacarecanga sem que o narrador precise desviar sua atenção para lá. Por sinal essa é uma técnica bem comum na obra ficcional de Erico Verissimo, que muitas vezes recorre a recortes de jornais e revistas para transportar o leitor a outro plano temporal e espacial, trazendo até ele informações distantes, sem comprometimento do fluxo narrativo. Esse recurso favorece a coerência interna do texto, uma vez que a opção pelo documento escrito anula construções complicadas no enredo para justificar o contato do personagem com determinada informação.

A mãe de Clarissa, com seu português deficiente, se mostra preocupada com os perigos da cidade grande, notadamente em relação aos bondes e automóveis. Também revela desconfiança em relação aos habitantes urbanos e elege como lugar de perigo o cinema. A preocupação da mãe com a situação da filha, jovem demais e por conseguinte ainda ingênua para enfrentar os riscos da capital, denota uma postura de dúvida em relação ao caráter do sujeito "moderno" e uma resistência em aceitar as novidades do progresso. 0 bonde, o automóvel e o cinema estão entre as principais novidades tecnológicas do início do século XX e, embora também estivessem presentes em municípios do interior, eram considerados símbolos urbanos por excelência.

A crise financeira da família também merece atenção da mãe de Clarissa. É por essa época que a economia gaúcha, baseada na agropecuária e no latifúndio, sofre fortes abalos por conta do processo de industrialização e de novos modelos de desenvolvimento. Desfazer-se das propriedades 
para poder pagar as dívidas passa a ser um recurso recorrente no campo. Esses problemas, mais notadamente a falência das estâncias gaúchas, são representados com mais profundidade em Música ao longe. Nesse romance, que se passa em Jacarecanga, Clarissa volta a ser protagonista, mais adulta, mas ainda incapaz de interpretar a crise familiar como resultado de algo maior, associado à falência da estrutura econômica fundada no século XIX e ao questionamento das tradições gaúchas valorizadas pelo regionalismo.

Voltando a Clarissa, a personagem está longe de sua terra, vivendo numa cidade grande, e sente falta das coisas simples das quais aprendeu a gostar, como a estância, o cachorro Sultão, a vaca Mimosa, a sesta da tarde, os roncos do pai, as noites claras, as manhãs douradas, o luar, o leite tépido e espumante na mangueira. Quando pensa em todas essas coisas, Clarissa pega um bloco de papel, tinta e caneta e escreve para os pais. Trechos da carta são intercalados com observações do narrador e se estendem por quatro páginas do romance. Algumas passagens:

Queridos pais:

$[\ldots]$

Estou com uma saudade tão grande de vocês

Deve botar ponto de admiração, ponto final ou três pontos? Não tem importância. Lá vai... uma admiração. Fica mais bonito. A professora de português disse que o ponto de admiração indica uma exclamação, serve também para dar mais força ao que se escreve. Pois bem. A saudade é uma coisa forte, muito forte mesmo.

Estou com saudade tão grande de vocês!

E depois o pai e a mãe não reparam, nunca estiveram em escola secundária, não fazem caso da gramática...

Felizmente agora as férias estão pertos.

Pertos ou perto? Caneta na boca, olhar vago, Clarissa procura solução para o problema. Por fim decide escrever - perto.

Segue:

A tia Zina e o tio Couto vão bem e mandam muitas lembranças... 0 tio Couto coitado...
Sorri. Couto coitado... Que figura é esta? Que vício de linguagem? Cacófato? Não. Porque não forma nome feio. Couto coitado... Pleonasmo? Também não.

0 tio Couto, coitado, ainda não arrumou emprego. E o senhor, papai, já vendeu o gado? Tenho tirado muitas notas boas, no exame só tenho medo da aritmética, mas, se Deus quiser, e a Virgem Santíssima, hei de sair aprovada se não cair regra de três composta, porque simples eu sei bem... (VERISSIMO, 2005, p. 108-109)

Nessa carta, interrompida várias vezes pelo fluxo de consciência e pelas atividades domésticas, a jovem Clarissa mostra-se preocupada basicamente com a correção da língua portuguesa e com a descrição da rotina na pensão onde mora com os parentes. Mesmo dirigindo-se a leitores semiletrados, a personagem procura escrever de forma correta, praticando nas cartas o aprendizado da escola, e levanta dúvidas gramaticais que surgem durante esse processo. Isso revela muito sobre a personagem, atenta a questões de língua portuguesa, mas ainda imatura para perceber os problemas sociais do meio em que habita. Ela faz uma observação sobre o tio Couto, desempregado, e uma pergunta dirigida ao pai, em dificuldade financeira. No entanto, Clarissa não chega a refletir sobre as causas e efeitos da situação de seus familiares, tanto no campo quanto na cidade.

Diferentemente do que faz Richardson em relação ao romance Pamela, Erico Verissimo não busca transmitir na epístola "uma expressão imediata de cada circunstância” (Watt, 2010, p. 203), mas, sim, uma expressão imediata de uma série de circunstâncias que definem o meio em que se desenvolve todo o enredo.

Nas cartas escritas pelo Dr. Winter ao seu amigo jornalista Karl von Koseritz, no episódio "A teiniaguá" de $O$ continente, o leitor descobre quais são as impressões do imigrante alemão em relação aos hábitos e costumes dos gaúchos de Santa Fé. Na correspondência entre Winter e Koseritz temos acesso a apenas uma carta do jornalista, na qual ele sugere a Winter trocar a cidade de Rio Grande por Porto Alegre ou pelas colônias 
alemãs de São Leopoldo. As outras cartas são sempre remetidas pelo médico.

No plano da ficção, a participação do médico tem uma função de "coro", na qual uma pessoa alfabetizada pode estabelecer comparações entre a civilização sul-americana e a europeia, bem como ver com um "olhar de fora" a vida em Santa Fé e na Província de São Pedro. Algo parecido observa Lajolo (2002, p. 66-67) em relação ao romance epistolar Lettres d'une peruvienne, publicado em 1747 por Mme. Grafigny e composto por 41 cartas. Muito embora nessa obra as cartas sejam escritas pela protagonista, Zília, uma indígena nativa, nos interessa em particular a ideia do romance transcultural que entrelaça Europa e América, conceito estudado por Ángel Rama (apud LAJOLO, 2002, p. 66). Alguns apontamentos que Lajolo faz em relação à Zília também podemos direcionar a Dr. Winter, já que neste caso também está em jogo os valores civilizacionais europeus, num sentido inverso ao do romance francês. Se em Lettres d'une peruvienne a sedução do público leitor teve a ver com o virtuosismo da transculturação tematizada, inclusive pelo tratamento de questões ideológicas, algo não muito diferente ocorre com o médico alemão em $O$ tempo e o vento, por sinal uma das personagens mais convincentes da trilogia. Temas ideológicos também perpassam a fala e a escrita de Winter, o que indica a hipótese de o conceito de transculturação narrativa poder ser aplicado tanto no romance latino-americano quanto sobre a América Latina, como defende Lajolo.

As impressões de Winter sobre a sociedade gaúcha da época aparecem pouco no diálogo com outros personagens e muito em seu fluxo de consciência, em que podemos conhecer o imigrante em sua luta para entender a cultura local, pontuando os valores e os costumes do gaúcho. No entanto, é nas cartas escritas a Koseritz que a personagem revela-se por completo como alguém triste, que enfrenta dificuldades de adaptação e encontra na epístola uma forma de diálogo possível, já que em Santa Fé não existe um interlocutor à altura de um médico formado em Heidelberg. Vejamos um trecho dessas cartas endereçadas a Koseritz:

Perdoa-me essas minúcias. Quando vivemos por muito tempo num mundo tão limitado e pobre como este, acabamos conferindo às suas intriguinhas, às suas pessoinhas e às suas coisinhas uma importância universal.

Mas este outono, meu caro Carlos, é grande aqui e em qualquer outra parte do universo. Aristóteles haveria de gostar de dias e campos como estes para as suas dissertações peripatéticas. Estou certo de que houve um erro qualquer na distribuição das raças. Quando Deus criou o mundo ele destinou a esta terra outras gentes que não estas. Haverá ainda um meio de corrigir esse erro? Eis aqui uma pergunta perigosa, que nos poderá levar a complicações tremendas." (VERISSIMO, 1956, p. 661-663 - grifos do original)

Ao perceber a terra mal aproveitada e o atraso material e intelectual do Rio Grande, Winter questiona se os nativos merecem essas paisagens. Para ele, Deus criou o mundo e destinou a região a outro povo que não o gaúcho. A ideia de superioridade da raça ariana estava no discurso cientificista do século XIX e era reproduzido por muitos imigrantes alemães no Brasil, entre eles Koseritz, que acreditavam de fato serem os únicos capazes de promover o progresso do Brasil. Em outro momento, Winter chega a sugerir o casamento de gaúchos com alemães, nunca com negros e índios, pois dessa miscigenação resultaria um futuro de desenvolvimento.

Saudoso em relação à Alemanha e a um amor não realizado, Winter vive em total desconforto no novo ambiente. Nas correspondências ele mistura assuntos sentimentais, identificados com o comportamento romântico do século XIX, com temas filosóficos e morais. Como se vê nesse trecho:

Espero que o meu barão tenha realizado os seus sonhos, que seu jornal seja um sucesso e a escola outro. Quanto a mim, sou um fracassado. O médico da municipalidade tem agora as preferências do nosso Junker local. [...] O meu caro amigo já reparou que, em última análise, uma pessoa não passa duma porção de paixões, cercada de incompreensão por todos os lados? Este pequeno arquipélago de Santa Fé não está propriamente no Mar Tenebroso, mas sob sua aparência de 
quietude e rotina tem também seus dramas. E eu, como médico, faço o curioso papel de lançadeira, indo e vindo a conduzir a frágil linha que costura esse tecido dramático. Creio que estou ficando literato, tão literato que não se admire o meu bom amigo se um dia eu lhe mandar sonetos ou pensamentos filosóficos para seu jornal. Pois dramas não faltam por aqui, meu caro. Eu os vejo, eu os cheiro, eu os ouço, eu os apalpo. Há dramas no casarão do velho Amaral. Dramas nas casas dos colonos da Nova Pomerânia. Dramas até no quintal do vigário, meu vizinho e inimigo. Drama há também no peito encatarroado do Dr. Nepomuceno. Mas o maior drama de todos está no Sobrado. Como médico - ah, a nobre, a sublime profissão médica! - não devo quebrar o sigilo sagrado; mas como velho tagarela que aprecia o espetáculo da vida, fico ardendo por contá-los ao mundo. Um dia ainda nos havemos de encontrar para uma longa palestra. Falaremos de tuas realizações, Carl, de teus projetos. Falaremos um pouco também sobre o passado. Diremos mal de Napoleão III, da Inglaterra e principalmente dessa augusta vaca, a rainha Vitória. (VERISSIMO, 1956, p. 697-698 - grifos do original)

Os dramas que envolvem os relacionamentos entre Bibiana, Luzia e Bolívar tornam-se os principais objetos de observação do médico de Santa Fé nessa e nas outras cartas. Como ele mesmo comenta, já que não existem teatros na vila, ao menos pode divertir-se com a comédia da vida privada, neste caso o Sobrado. Nas cartas escritas por Winter encontram-se aspectos da cultura regional de uma forma geral, dos relacionamentos pessoais a partir dos habitantes do Sobrado, como uma espécie de microcosmo da oligarquia rural a partir de seu espaço privado, e por fim descrições do próprio drama do remetente. $\mathrm{O}$ mais interessante e que obtém melhor efeito na tecitura narrativa são, sem dúvida, os comentários do médico sobre os costumes locais.

Nesse ponto existe uma confluência entre o apontamento de Watt sobre as vantagens literárias da forma epistolar na ficção e a opinião de Erico Verissimo sobre a sua personagem. Watt afirma que a principal vantagem da narrativa epistolar "consiste no fato de as cartas serem a prova material mais direta da vida interior de seus autores" e que a realidade dessas memórias é "do tipo que revela as tendências subjetivas e privadas do autor com relação ao destinatário e às pessoas mencionadas, bem como seu próprio íntimo" (2010, p. 202). Em seu livro de memórias, o escritor conta como surgiu a personagem Dr. Winter, inspirada em um médico alemão que "apresentou suas credenciais à Câmara Municipal" de Cruz Alta em 1852, conforme consta em uma monografia sobre o município (VERISSIMO, 1995, p. 299). Erico afirma que Winter nasce de uma necessidade de haver uma personagem que fizesse "o papel de 'coro' daquela comédia provinciana" e se pergunta se, quanto às ideias e reações ao ambiente, não seria o médico o porta-voz da relutância do escritor "em aceitar o Rio Grande e o seu povo".

Muito diferente são as cartas escritas pelo padre missionário Juan Bautista Otero, em Incidente em Antares, pelo repórter Roberto e pela suicida Joana Karewska, em $O$ resto é silêncio. A primeira aparece como um documento histórico, empregado para fornecer mais informações ao leitor sobre os primeiros habitantes de Antares, à época ainda chamada de Povinho da Caveira. Datada de 4 de dezembro de 1832, a carta do padre ressalta as relações carnais entre índios e portugueses e o seu trabalho apostolar, que consiste em realizar batizados e casamentos. Diz um trecho da carta:

Aqui vivem muitos índios e índias em estado de indigência e, o que é ainda pior em pecaminosa mancebia. Por outro lado, a ausência de mulheres da raça branca neste aldeamento leva os homens de origem portuguesa a servirem-se dessas indígenas para a satisfação de sua luxúria. O próprio Sr. Bacariano, segundo me informou pessoa digna de fé, é pai de quase uma dezena de filhos naturais com várias destas silvícolas, mas não os batiza nem legitima. [...] (VERISSIMO, 2000, p. 7 - grifos do original)

Os apontamentos do missionário complementam as informações do diário do aventureiro francês Gaston Gontran d'Auberville, que aparecem logo no início do romance para dar conta de uma descrição da localidade em princípios do século XIX. Na carta de Juan Bautista Otero fica clara a intenção do narrador de destacar menos as questões de ordem religiosa, por conta do 
pecado da luxúria e da possibilidade de haver casos de incestos na vila, do que a miscigenação entre o português e o índio, coisa natural tendo em vista as condições de isolamento da região e a falta de mulheres brancas. No final da carta, o padre escreve que o Sr. Bacariano pretendia se casar, em Alegrete, "com uma moça, de nome Angélica, filha dum abastado estancieiro daquela localidade" (VERISSIMO, 2000, p. 7). Em outras palavras, essa observação corrobora o propósito do narrador na primeira parte do romance, que é de traçar um perfil da oligarquia rural de Antares, ressaltando, entre outros aspectos, as relações de mando e poder exclusivas de um grupo que adquire força com a violência e o jogo de interesses - no caso supracitado, o casamento arranjado para aumento ou manutenção das posses.

A carta do repórter Roberto tem uma finalidade bem diferente. Por conta da estrutura do romance $O$ resto é silêncio, em que diversas histórias e vidas se cruzam, o narrador tem dificuldade para se aprofundar na psicologia das personagens. Entre as testemunhas do suicídio da jovem que se atira do alto de um prédio no centro de Porto Alegre, algumas delas são mais simpáticas ao narrador e conseguem se destacar na trama. Sobre outras, como o jovem idealista Roberto, pouco se sabe. A carta que ele escreve à namorada Nora ajuda o leitor a entender a sua postura individual frente à sociedade.

Nora

Escrevo-te às três da manhã. Cheguei à conclusão de que temos de acabar com tudo. Nem sei mesmo como as coisas chegaram a este ponto. Pertencemos a mundos completamente diferentes e essa história toda não vai dar certo. Segundo as leis da sociedade em que vives, leis essas a que obedeces, queiras ou não queiras, duas criaturas que se desejam só se podem unir pelo casamento, com juiz, padre e uma papelama infernal. Essas mesmas leis mandam que os cônjuges (não é assim que se diz?) montem casa, constituam família e tenham muitos filhos embora não possuam recursos para dar-Ihes comida. Exigem também que vivam juntos o resto da vida, mesmo depois que deixarem de gostar um do outro. Se um dia o marido, por exemplo, deixar a mulher, o teu mundo e a sua moral não permitirão que ele diga isso à esposa nem que apareça com a 'outra' em público, de sorte que ele terá de manter essas relações escondidas. Pode montar-Ihe casa passar suas noites com ela e tudo ficará muito bem se ele tiver habilidade para ocultar o caso. O que importa é que a sociedade não seja afrontada. O essencial é manter as aparências, levar uma vida de hipocrisia, criar os filhos de acordo com essa moral absurda. Mas o que te digo é que eu não tenho dinheiro para manter um 'lar' como a tua classe exige. Também não tenho estômago para suportar a moral do teu mundo. Vamos acabar com tudo enquanto é tempo enquanto não temos de que nos arrepender. Não acredito que vás sentir muito. Só lamento ter roubado o teu tempo. Não creio que me ames. (O ames estava riscado e substituído por gostes de mim). Às vezes penso que estás representando e que te portas como uma espécie de personagem dos romances de teu pai.

Cheguei agora da rua, estou cansado e irritado. 0 mundo anda muito besta e muito triste. Nunca vi tanta miséria e tanta incoerência.

Tínhamos combinado um encontro para hoje à esquina da praça. O melhor é que tudo fique acabado desde já. Não me esperes. (VERISSIMO, 1994, p. 204-205 - grifos do original)

A partir do conteúdo dessa carta o leitor é, de fato, apresentado ao repórter Roberto. Mais adiante, durante uma entrevista com o homem de negócios Aristides Barreiro, a personagem vai se revelar por completo como uma pessoa inconformada com as desigualdades sociais e a insensibilidade dos ricos. No texto direcionado à namorada, Roberto descreve o seu pensamento em relação aos costumes e acomodações envolvendo a família e a religião. A personagem mostra-se ressentida com as convenções impostas pela sociedade e disposta a seguir um caminho diferente. Além disso, Roberto sofre por perceber os efeitos nocivos da nova ordem capitalista e se recusa a aceitar o rumo atual das coisas.

Outro caso em $O$ resto é silêncio é a carta escrita por Joana Karewska e endereçada ao escritor Tônio Santigo, única personagem do romance que se interessa em descobrir a história de vida da jovem suicida. Como Joana não tem voz ativa na trama, sendo apenas o elemento que deflagra os acontecimentos logo nas primeiras páginas da narrativa, a carta escrita por 
ela é o único registro pessoal que o leitor tem à disposição para saber um pouco mais sobre a personagem.

Ilmo. Snr. Antônio Santiago

Sou uma pobre moça que trabalha na 'Loja Americana' e me acho muito parecida com as personagens dos seus livros. Meus pensamentos são iguais aos da Lúcia, e meu caso é igual como o dela. Se o senhor soubesse da minha vida é que ia fazer um romance muito célebre e que parece impossível. Quer me dar uma alegria venha me visitar que eu trabalho na sessão de brinquedos, no fundo à direita de quem entra. Sou loura, meia magra e tenho os olhos azul. 0 gerente é proibido conversas, mas o senhor pode fazer de conta que está comprando brinquedos e então falamos. Tenho muita coisa para lhe contar. Ando muito infeliz estes últimos tempos e acho que vai asuceder uma desgraça. Só o senhor pode me salvar. Venha.

Da vossa infeliz servidora muito lealmente

(VERISSIMO, 1994, p. 118 - grifos do original)

Joana Karewska.

Embora a narrativa de $O$ resto é silêncio não explore a fundo o mistério da morte de Joana, dispensando a técnica do romance policial, ${ }^{1}$ essa carta consiste em uma peça-chave para o romancista Tônio Santiago entender o caso. A partir dela, Santiago realiza uma investigação particular para descobrir a história da jovem e as motivações de sua morte, imaginando que pudesse haver ali matéria-prima para um romance. Ao receber a carta, o escritor passa a se sentir culpado pelo suicídio porque interpretou o apelo de Joana como brincadeira de um leitor. Além disso, Joana identifica-se com uma de suas personagens, detalhe que colabora para aumentar a sensação de culpa.

A morte de Joana atua na estrutura de $O$ resto é silêncio como "uma pedra que cai no lago"2, formando círculos que se expandem em todas as

\footnotetext{
${ }^{1}$ Erico Verissimo afirma no prefácio da obra, escrito para a edição de 1966, que deveria ter dado mais espaço e tempo ao inquérito de Tônio Santiago. Segundo a autocrítica do autor, isso teria dado à história "mais encanto e mistério, bem como um maior interesse novelesco". (VERISSIMO, 1994, prefácio)
} 2 Refiro-me ao título do primeiro capítulo do romance, intitulado "Uma pedra caiu no lago". direções. Esses "círculos" afetam de alguma forma o destino de diferentes personagens, mesmo daqueles para os quais a queda de uma jovem do alto de um prédio não passe de uma quebra de rotina. A carta de Joana chega às mãos de Tônio Santiago antes do suicídio, mas entra na narrativa mais tarde, como mais um reflexo da pedra que cai no lago. A carta antecipa as motivações da morte da jovem - suicídio e não assassinato - e alça o escritor ao posto de personagem principal do romance, apesar de não haver personagens centrais na narrativa.

Em $O$ senhor embaixador as cartas surgem em certos momentos para revelar aspectos da vida íntima das personagens, esclarecer o desencadeamento de eventos históricos ou descrever esses mesmos eventos. Pablo Ortega e Glenda Doremus têm relações familiares conflituosas e as cartas escritas por seus pais revelam pontos determinantes do temperamento das personagens. Ambas são vítimas do cerceamento dos pais, mesmo vivendo distante. A carta chega a Washington para avisar que os protetores ainda têm influência sobre a vida de seus filhos. Não raro apelam à chantagem emocional. Na primeira parte do romance, intitulada "Credenciais", na qual as personagens centrais são apresentadas pelo narrador, Glenda recebe uma carta de seu pai.

Querida filha: Por que não voltas para casa? Sei que Washington deve estar linda agora com as cerejeiras floridas, mas aqui em Atlanta os pessegueiros estão também em plena floração. Tua mãe e eu não podemos compreender por que ainda não tomaste uma resolução firme quanto ao que queres estudar. $O$ ano passado foi Inglês e Literatura. Este ano é essa tolice de História da América Latina. Que utilidade prática isso pode ter?

Tua mãe não anda se sentindo bem, está com flebite, presa à cama, e andamos todos muito preocupados com sua saúde. Como eu, tua mãe ficou triste porque não nos visitastes nas tuas últimas férias de verão e porque nos comunicas agora que talvez não possas estar conosco nas de Natal. [...] (VERISSIMO, 1997, p. 79, - grifos do original) 
Após a leitura, Glenda rasga a carta e atira os pedaços num cesto de lixo. Retraída e desconfiada, ela tem dificuldade para estabelecer contatos sociais. Quando jovem, acusou falsamente um negro de estupro. $O$ homem foi espancado até a morte e, descoberta a mentira, seus pais e outros envolvidos no caso foram processados. Seu pai faz referência ao assunto proibido na carta, o que aumenta a raiva da personagem. 0 "segredo" de Glenda é apenas insinuado nessa carta e revelado em sua completude apenas no final do romance.

Algo parecido ocorre com Pablo Ortega, secretário da embaixada da República do Sacramento. O pai sofre de problemas cardíacos e todas as decisões do filho precisam levar isso em consideração. Quando a revolução é deflagrada no Sacramento, Pablo decide abandonar a embaixada e seguir os revolucionários. Ele recebe uma carta da mãe:

Meu filho: Tua decisão intempestiva de deixar o serviço diplomático nos surpreendeu e abalou profundamente. Primeiro pensei em ocultar o fato a teu pai, pois ultimamente ele anda sentindo palpitações, dores no peito e um pouco de falta de ar. Compreendi, porém, que mais tarde ou mais cedo, ele viria a saber de tudo por um amigo desavisado ou uma notícia de jornal, e então o choque seria muito mais forte. Contei-lhe a história aos poucos, da maneira mais suave possível. Não podes imaginar o quanto teu gesto o deixou magoado e triste.

Por mais que me esforce, não posso compreender por que não tiveste ao menos a delicadeza de nos consultar antes de dar esse passo que tanto vai dificultar tua volta à tua terra e a teu lar. [...]

Teu pai te manda a sua bênção e o mesmo faz tua mãe, que a despeito de tudo ainda te quer e te beija carinhosamente

(VERISSIMO, 1997, p. 301-302 - grifos do original)

Isabel.

O "a despeito de tudo" que finaliza a carta irrita Pablo profundamente. No entanto, os acontecimentos da esfera política que levam a um golpe de Estado na República do Sacramento, seguido pela revolução, tinham agido no espírito de Ortega como "uma espécie de vacina que o tornava imune ao vírus da chantagem materna" (VERISSIMO, 1997, p. 302). Personagem de personalidade forte, Ortega não apenas integra o movimento revolucionário, como também destaca-se por assumir a tarefa de defender Gabriel Heliodoro, ex-embaixador e um dos líderes do golpe, no julgamento popular promovido pela revolução.

Além da psicologia de personagens complexos que circulam pelos ambientes diplomáticos de Washington, a estrutura de $O$ senhor embaixador também precisa dar conta da verossimilhança que envolve a fictícia República do Sacramento. Afinal de contas a preocupação central da narrativa é representar o contexto político, econômico e social das repúblicas da América Latina, basicamente a partir da participação de intelectuais na política militante. Nesse sentido a história do passado e do presente da República do Sacramento é contada por meio dos diálogos das personagens, em suas ações e reações, e em cartas como esta remetida pelo ditador Juventino Carrera ao embaixador Gabriel Heliodoro:

Meu querido compadre: A situação aqui não anda boa. Como sabes, conforme determina a Constituição, temos de fazer eleições presidenciais em novembro deste ano. Pensei que estava preparado para entregar o Governo ao meu sucessor legal e retirar-me definitivamente para a minha granja de Los Plátanos, pois ando meio doente e muito cansado. Infelizmente minha missão não está ainda cumprida, quero deixar pelo menos começadas as grandes obras da estrada transsacramentenha, e terminados muitos outros empreendimentos que já iniciei. Por outro lado não acho que nosso país esteja preparado para resistir às comoções dum pleito presidencial. Dizem que o diabo sabe muito mais por ser velho do que por ser diabo. Pois este teu compadre, raposa velha, anda farejando algo no ar. Sinto uma certa inquietação não só na Universidade, entre professores e estudantes, como também nas ruas e até nas camadas mais altas da nossa sociedade. [...]

Que providências tomar, então, para evitar que este país caia nas mãos dos comunistas ou dessa plutocracia sacramentenha que no fundo nunca me aceitou, nunca se conformou de ser governada por um homem de origem humilde como eu? O remédio, me parece, é um novo golpe de Estado. Conferenciei ontem sigilosamente com o Ministro da Guerra, que pensa como eu e me garante o apoio total e incondicional do Exército. [...] (VERISSIMO, 1997, p. 165-166 - grifos do original) 
O conteúdo dessa carta revela inicialmente uma proximidade atípica para um presidente e um embaixador. Ao dirigir-se ao embaixador como "Meu querido compadre", Juventino Carrera deixa evidente muito mais o tom de confissão do que de orientação ou ordem. Por isso pode usar palavras como "o remédio é esperar que os agitadores botem a cabeça de fora para agirmos" (VERISSIMO, 1997, p. 167). Além disso, o propósito da carta nesse contexto é apresentar ao leitor a maneira com que muitos políticos latinoamericanos trabalharam para derrubar ou implantar ditaduras na América Latina, o que colabora para garantir a verossimilhança da trama. Isso fica evidente em frases como "seremos obrigados a inventar um novo plano subversivo e assustar mais uma vez com o fantasma do comunismo..." e "encontraremos um bom pretexto para o golpe" (VERISSIMO, 1997, p. 167).

Em outra passagem do mesmo romance, o correspondente norteamericano William B. Godkin, especialista em assuntos latino-americanos, recebe em Washington uma carta enviada pelo colega que trabalha na cobertura dos eventos no Sacramento. Parte do conteúdo da correspondência é transcrito pelas palavras do narrador, outra parte aparece na forma como teria sido lido por Godkin.

Seria excessivo otimismo contar com a derrota completa de Carrera nas próximas semanas ou mesmo durante o próximo mês. A força aérea inteira ainda se mantém fiel ao Governo, bem como as poderosas guarnições de Cerro Hermoso e Puerto Esmeralda. Mas há um problema que está começando a perturbar seriamente o ditador e seus generais: a escassez crescente de armas e munições, agravada pelo embargo imposto pelos Estados Unidos à venda de material de guerra tanto aos legalistas como aos rebeldes. Assim sendo, não será exagero afirmar que "El Libertador" não poderá festejar o próximo Natal no Palácio do Governo. Terá de fazê-lo no exílio ou no inferno. (VERISSIMO, 1997, p. 308 - grifos do original)

A carta que chega às mãos de Godkin relata a situação conflituosa na República do Sacramento enquanto o narrador está envolvido com as personagens em Washington. Com essa estratégia, o leitor tem uma ideia ampla dos acontecimentos, tanto de detalhes que culminarão no golpe e na revolução na ilha quanto do fluxo de consciência das personagens centrais do romance.

No segundo caso, os dramas desencadeados pelo golpe militar e a deflagração da revolução afetam personagens que querem se envolver no imbróglio e outros que querem fugir dele. Jorge Molina pertence ao grupo dos que não querem encarar a luta e a melhor medida encontrada para isso é o suicídio, que no final não se consuma. É por meio de uma carta que ele se despede da melhor amiga, Miss Ogilvy, e deixa algumas instruções importantes para serem tomadas após a sua morte.

Perdoe-me pelo choque que porventura eu lhe possa ter causado. Reconheço que entrar num apartamento e encontrar um defunto em cima duma cama não deve ser coisa muito agradável. Em todo o caso, como não acredito que tenha por mim o menor sentimento de afeição, sei que o choque não será muito grande, e esta ideia atenua um pouco o constrangimento que agora sinto.

Nem sequer tentarei explicar-lhe os motivos por que me suicido. Seria muito complicado e tedioso, e de qualquer modo minhas razões lhe soariam falso. $O$ importante é deixar bem claro que ninguém senão eu próprio é responsável por este meu ato que nem sequer é de desespero. Estou em plena posse de minhas faculdades mentais.

Aceite, portanto, o fato consumado e não faça perguntas a respeito dele a si mesma nem aos outros. E não me queira muito mal por todo o incômodo que lhe causo.

Rogo-lhe a fineza de aceitar o pequeno presente que aqui incluo na forma dum cheque de mil dólares. $E$ de expedir as cartas que deixo em cima desta mesa, e entre as quais se encontra uma dirigida às autoridades policiais de Washington. $[\ldots]$

Obrigado, Miss Ogilvy, obrigado por tudo. Creia que sempre tive pela sua pessoa o maior respeito e admiração. Atenciosamente... (VERISSIMO, 1997, p. 343-344 - grifos do original)

Como nas cartas analisadas até aqui, essa também ajuda a revelar características da personagem até então não apresentadas pelo narrador. 
Molina mostra-se consciente de seu ato, despido de mágoas ou ressentimentos. A ausência de frases desesperadas, que seria aceitável para alguém que está prestes a cometer suicídio, e uma consciência exagerada da inutilidade do corpo, desvela um sujeito despreocupado com o que pode vir a acontecer após a sua morte. Essa é a imagem mais forte da personagem que fica para o leitor, justamente as palavras de uma carta de despedida, da vida para a morte.

Lajolo (2002, p. 62) levanta a hipótese de que o sucesso do romance epistolar reside no fato de que "ao se estruturarem como cartas, tornavam-se bastante familiares a seus leitores", na medida em que havia uma homologia entre práticas sociais cotidianas de linguagem e de escrita e a mímese dessas práticas na literatura. Não por acaso, ainda segundo Lajolo (2002, p. 64), o atestado desse sucesso pode ser verificado na frequente menção a cartas e bilhetes na ficção não epistolar, a exemplo de alguns romances de José de Alencar, os quais "transformam-se em fator de estruturação do texto".

Essa observação de Lajolo pode nos ajudar a entender a grande aceitação por parte do público de Olhai os lírios do campo, o primeiro sucesso literário de Erico Verissimo e que garante, naquele momento, em 1938, a independência financeira do escritor, que passa a dedicar-se exclusivamente à literatura. Atento aos costumes de seu tempo, Erico certamente sabia da importância da epístola como fator emocional nas relações sociais e utiliza isso a favor de sua criação literária ao narrar a história de amor entre os médicos Eugênio e Olívia.

As cartas escritas por Olívia são dispostas na narrativa como uma espécie de flash back, uma vez que são lidas por Eugênio após a morte de sua amada e remetem a momentos de um passado remoto. Nesses escritos, Olívia recupera fatos e diálogos que haviam escapado do narrador, bem como antecipa ações que devem ser realizadas por Eugênio. A primeira carta Olívia escreve poucas horas antes de morrer, será lida após o sepultamento, e ocupa pouco mais de três páginas do romance. Vejamos alguns trechos:

Meu querido: O Dr. Teixeira Torres acha que a intervenção deve ser feita imediatamente e daqui a pouquinho tenho que ir para o hospital. Não sei por que me veio a ideia de que posso morrer na mesa de operações e aqui estou te escrevendo porque não perdoaria a mim mesma se fosse embora desta vida sem te dizer umas quantas coisas que não te diria se estivesse viva.

$[\ldots]$

Hoje tens tudo quanto sonhavas: posição, social, dinheiro, conforto, mas no fundo te sentes ainda bem como aquele Eugênio indeciso e infeliz, meio desarvorado e amargo que subia as escadas do edifício da Faculdade, envergonhado de sua roupa surrada. Continuou em ti a sensação de inferioridade (perdoa que te fale assim), o vazio interior, a falta de objetivos maiores. Começas agora a pensar no passado com uma pontinha de saudade, com um pouquinho de remorso. Tens tido crises amargas e eu chego até a amar o teu sofrimento, porque dele, estou certa, há de nascer o novo Eugênio.

[...]

Antes que me esqueça: Na gaveta da cômoda há um maço de cartas que te escrevi de Nova Itália expressamente 'para não te mandar'. Agora podes lê-las todas. Não encontrarás nada do meu passado, do qual nunca te falei e sobre o qual tiveste a delicadeza de não fazer perguntas. E pena. Gostaria que soubesses tudo, que visses como minha vida já foi feia e escura e como lutei e sofri para encontrar a tranquilidade, a paz de Deus,

Adeus. Sempre aborreci as cartas de romance que terminam de modo patético. Mas permite que eu escreva.

\section{Tua para a eternidade}

Olívia.

(VERISSIMO, 1997, p. 152-156 - grifos do original)

Nessa carta, em que fica marcado um tom de despedida, Olívia prevê sua morte na mesa de cirurgia e aproveita a ocasião para vasculhar o caráter de Eugênio. Nesse momento sabemos mais sobre as angústias e inseguranças do protagonista a partir dos escritos de Olívia do que pela voz do narrador. Além de mexer com sentimentos que incomodam a personagem, como sua sensação de inferioridade em relação às pessoas de melhor posição social, 
a carta procura orientar Eugênio a superar seus dramas pessoais, o que seria possível com uma revisão de seus valores morais. De uma maneira direta, sem subterfúgios, Olívia afirma que a infelicidade de Eugênio está relacionada a sua busca por dinheiro, prestígio e poder. Para ela, "quando o amor ao dinheiro, ao sucesso nos estiver deixando cegos, saibamos fazer pausas para olhar os lírios do campo e as aves do céu" (VERISSIMO, 1997, p. 154).

Opiniões como essa, que dizem muito sobre as diferenças entre Eugênio e Olívia, não aparecem nos diálogos entre as duas personagens. É por meio da carta que Olívia revela-se por completo e ao mesmo tempo expõe as fraquezas de Eugênio, deixando transparecer a crítica contra o materialismo e a desigualdade social. Mais do que uma história de amor entre duas personagens, que por sinal não se concretiza em união, a narrativa de Olhai os lírios do campo fala das implicações provocadas pela ambição por dinheiro e reconhecimento. Vindo de uma família pobre, Eugênio sente vergonha de sua origem e corrompe-se ao se casar por interesse com uma moça rica. Olívia fica em segundo plano, sempre a assombrar a consciência de Eugênio.

Nas páginas subsequentes, as cartas escritas por Olívia quando de sua estadia em Nova Itália, nunca remetidas, mantêm uma linha de discurso semelhante. A personagem permite-se conhecer em sua completude, tanto para o destinatário quanto para o leitor do romance. Se na primeira parte da obra o narrador está mais interessado nos dramas de Eugênio, ocupandose pouco da psicologia de Olívia, na segunda parte ocorre um equilíbrio na atuação das personagens: ele por meio de ações práticas, sempre atormentado pelos erros cometidos no passado, ela por meio da memória. Os registros deixados por Olívia esclarecem pontos que haviam ficado obscuros na trama - o período em que ela vive em Nova Itália, o nascimento da filha do casal, etc. - e também são decisivos para determinar o futuro de Eugênio.
Procurar nossa felicidade através da felicidade dos outros - aconselhava Olívia noutra carta sem data. - Não estou pregando o ascetismo, a santidade, não estou elogiando o puro espírito de sacrifício e renúncia. Tudo isso seria inumano, significaria ainda uma fuga da vida. Mas o que procuro, o que desejo, é segurar a vida pelos ombros e estreitá-la contra o peito, beijá-la na face. Vida, entretanto, não é o ambiente em que te achas. As maneiras estudadas, frases convencionais, excesso de conforto, os perfumes caros e a preocupação de dinheiro são apenas uma péssima contrafação da vida. Buscar a poesia da vida fora da vida será coisa que tenha nexo? (VERISSIMO, 1997, p. 174 - grifos do original)

Watt observa que o método epistolar leva o escritor a "produzir algo aceitável como a transcrição espontânea das reações subjetivas dos protagonistas aos fatos na medida em que estes ocorrem e, assim, romper com a tendência clássica da seletividade e da concisão [...]” (2010, p. 203). As desvantagens desse uso seriam a implausibilidade, a repetição e a prolixidade. Por outro lado, a principal vantagem da carta seria o fato de ser “a prova material mais direta da vida interior de seus autores" (Ibid., p. 203).

No caso de Erico Verissimo, podemos concluir que seu objetivo ao recorrer a cartas em seus romances é, de fato, transcrever de forma espontânea as reações subjetivas das personagens, mas, por outro lado, sem a intenção de romper com a tendência da seletividade e da concisão. Em se tratando de estrutura, Erico Verissimo procura aplicar na sua obra qualquer técnica apreendida da tradição literária que sirva para sustentar a trama e fortalecer a verossimilhança, desde alguns elementos formais do método epistolar, como vimos, passando pelo entrecruzamento de perspectivas do contraponto, o fluxo de consciência do modernismo, a preocupação com questões sociais do regionalismo e o impacto de grandes eventos históricos sobre personagens comuns, característica cara ao romance histórico, entre outras.

Justamente por seus romances não serem epistolares como os analisados por Watt, mas, sim, apenas apropriarem-se da técnica para 
colocá-la a serviço da configuração estrutural de sua ficção, eles não pecam por implausibilidade, repetição ou prolixidade. Muito pelo contrário, as cartas coadunam-se de maneira harmônica com a narrativa, contribuindo para articular o tecido estrutural como um todo. Na obra de Erico Verissimo a epístola surge em certos momentos para nos revelar o que há de mais secreto na vida íntima das personagens. Em outros, apresenta-nos sinais importantes para a compreensão do contexto histórico representado.

\section{Referências}

LAJOLO, Marisa. Romance epistolar: o voyeurismo e a sedução dos leitores. Matraga, Rio de Janeiro, v. 1, n. 14, p. 61-75, jan.-dez. 2002.

LUBBOCK, Percy. A técnica da ficção. Tradução Octavio Mendes Cajado. São Paulo: Cultrix; Editora da Universidade de São Paulo, 1976.

RAMA, Ángel. Transculturación narrativa en América Latina. México, Siglo XXI, 1985.

VALENTIM, Claudia Atanazio. O romance epistolar na literatura portuguesa da segunda metade do século XX. 2006. 116 f. Tese (Doutorado em Letras) - Universidade Federal do Rio de Janeiro (UFRJ), Rio de Janeiro, 2006.

VERISSIMO, Erico. Clarissa. 5. ed. São Paulo: Companhia das Letras, 2005.

VERISSIMO, Erico. Incidente em Antares. 49. ed. São Paulo: Globo, 2000.

VERISSIMO, Erico. Música ao longe. 38. ed. Rio de Janeiro: Globo, 1987.

VERISSIMO, Erico. Olhai os lírios do campo. 72. ed. São Paulo: Globo, 1997.

VERISSIMO, Erico. O senhor embaixador. 21. ed. São Paulo: Globo, 1997.

VERISSIMO, Erico. O tempo e o vento I - O continente. Porto Alegre: Globo, 1956. v. 2.

VERISSIMO, Erico. Solo de clarineta. 20. ed. São Paulo: Globo, 1995. v. 1.

WATT, Ian. A ascensão do romance: estudos sobre Defoe, Richardson e Fielding. Tradução Hildegard Feist. São Paulo: Companhia das Letras, 2010.

Recebido em 20 de dezembro 2015.

Aceito em 20 de maio de 2015 